An Elementary Laboratory

Study in Soils,

Prepared by

Prof. Joseph A. Jeffery

of the M.A.C.

S

593

.54

\title{
For the Schools of Michigan
}

Published by the State Superintendent of

Public Instruction. 

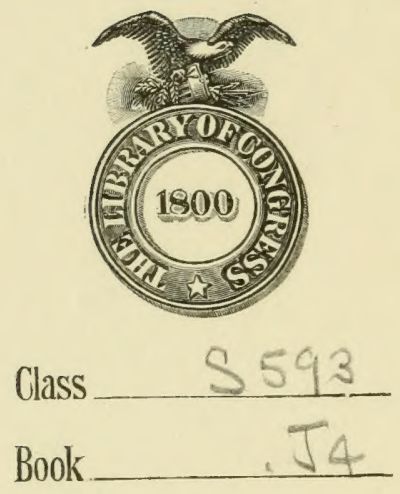

Copyrighht $\mathrm{N}^{0}$.

COPIRIGHT DEPOST. 
AN

\section{ELEMENTARY LABORATORY STUDY}

IN

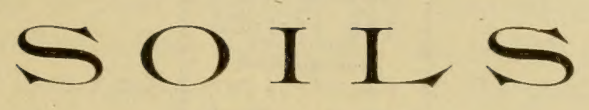

FOR THE

\section{SCHOOLS OF MICHIGAN}

JOSEPH A. JEFFERY, Professor of Agroniomy.

Michigan' Agricultural College, Lansing.

Published by the

Superintendent of Public Instruction. 


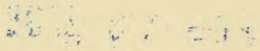

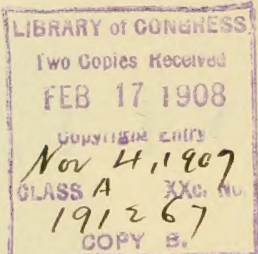

Copyright, 1907,

BY JOSEPH A. JEFFERY.

$\therefore \vdots \vdots$ 


\section{STATE OF MICHIGAN,}

\section{DEPARTMENT OF PUBHC INSTRUCTION.}

Lansing, Michigan, January 2, 1908.

\section{To Commissioners, Superintendents and Teachers:}

For a number of years educators have been advocating nature study as a part of the public school curriculum, and at the present time there is a strong demand that agriculture be taught in the public schools. In order to assist superintendents and teachers in giving definite instruction along these lines, Professor Joseph A. Jeffery of the Michigan Agricultural College has prepared this pamphlet entitled An Elementary Laboratory Study in Soils. The material presented dres not require an extended knowledge of chemistry and physics on the part of the teacher, and yet it deals with the vital points in this most important subject. The Agricultural College is doing a great work for the State of Michigan, and we believe that the distribution and use of this pamphlet in our schools will give splendid opportunity for study on the part of our young people, and at the same time cultivate a taste for agricultural pursuits. With this end in view the Department hereby expresses its appreciation of the services of Mr. Jeffery, and presents this pamphlet to the teachers of the State as a ground work for some definite instruction and study in the subject of soils.

Very respectfully,

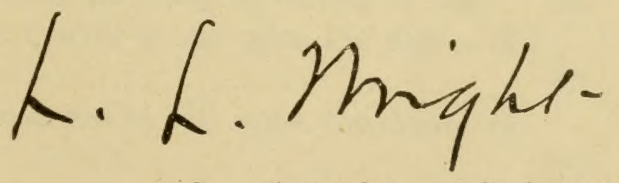

Superiutendent of Public Instruction. 



\section{TABLE OF CONTENTS.}

Introduction........................... 7

Equipment-laboratory ..................... 9

Preliminary exercise . . . . . . . . . . . . . . . . 10

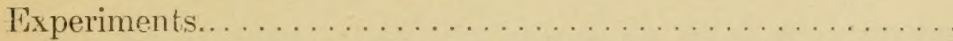

I. Pore space in soil-artificial............... 11

II. Specific gravity of soil................. 12

III. Pore space in soil-natural............... 13

IV. Weight of soil-under artificial conditions . . . . . 16

V. Water-holding power of soils-artificial........ 17

VI. Water-holding power of soils-as affected by the presence of organic matter.............. 18

VII. Water-holding power of soils-as affected by the presence of clay................... 18

VIII. Water in soils under natural eonditions.......... 19

IX. Water in soil when plants cease to grow........ 20

X. Moisture in air-dry soil ................. 22

XT. Moisture losses from eultivated and uncultivated soil surfaces...................... 22

XII. Effect of dry-earth mulches upon moisture losses.... 25

XIII. The effect of water in the puddling or baking of soils..

XIV. The effect of organic matter in soil upon the degree of puddling ....................... 26

$\mathrm{XV}$. The effect of sandy material in soil ipon the degree of puddling . . . . . . . . . . . . . . . . . . 27

XVI. A study of the variation in temperature of natural field or garden soils during the day at depths of $0,3,6$, and 12 inches respectively.............. 28

XVII. A study of the variation in temperature of natural field or garden soils during the day at lesser depths than in Experiment XVI ................ 29

XVIII. The effect of slope upon the temperature of the soil. .

XIX. The effect of color upon the temperature of soil (with air-dry soils in laboratory) ............... 30 
Page, Hours.

XX. The effect of color upon the temperature of soils (with moist soil and field conditions) . . . . . . . 32

XXI. The effect of moisture upon the temperature of the soil 33

XXII. The effect of tilth upon the temperature of the soil 34

XXIII. The effect of smoothness of surface upon soil tempera- 


\section{INTRODUCTION.}

The object of this course is to give to the pupil an opportunity to demonstrate for himself a few of the more important facts concerning soils and soil management. It is believed that when he has done this, his reading upon these things will be much more intelligently done and their application to farm practice will be more fully appreciated.

The teacher may find it desirable to change the order of the experiments; he may desire to change the plan of some of them. The discussions following some of the experiments may suggest other experiments, and it will doubtless add much to the interest of the work to allow pupils, from time to time, to develop and perform an original experiment so suggested. It will often be necessary to assist the pupil to a proper interpretation of his results in such an experiment.

The results of every experiment should be discussed-

First, As to their bearing upon farm practice so far as the pupils are acquainted with it, and

Second, As to how far they illustrate or confirm anything they may have read in the text books or elsewhere, or may have observed in practice. 



\section{LABORATORY EQUIPMENT.}

It is desirable, of course, to have a regularly equipped laboratory. It need not necessarily be a large room or expensively equipped. There should be some tables to work on. There should be a drying oven, one gourl balance weighing to one-tenth gram, a kitchen scale or its equivalent, ranging from one ounce to at least twenty-four pounds. If the building is not supplied with gas, there should be a gasoline stove and an aicohol limp.

In addition to the above, the following apparatus and "material will be needed:

2 doz. deep gallon jars.

5 doz. one-quart pudding or bean pans.

2 doz. two-quart pudding or bean pans.

2 doz. 8-inch pie tins (with nearly square shoulders if they can be secured).

1 doz. coffee cups.

10 feet No. 12 galvanized wire.

1 garden rake.

1 garden hoe.

1 garden spade.

24 -inch $\times 4$-inch $\times 4$-inch boxes of wood or metal without covers (see Fig. 3.)

1 soil sieve about 18 inches $x 30$ inches and 4 inches deep, with s(reen having 6 meshes to the inch (see Fig. 2).

1 fine meal sieve.

2 soil tubes (say $1 \frac{1}{2}$ inch by $3 \frac{1}{2}$ inches).

1 funnel rack, to carry 8 fumnels (see Fig. 9).

6 small soil scoops of bone, tin or wood.

J iron rod, $\frac{3}{8}$-inch by 18 inches long, rounded at end.

3 granite ware quart cups.

6 small rods of wood, $\frac{1}{2}$-inch by 12 inches long.

1 straight edge 16 inches long.

1 gauge (see Fig. 10a).

12 accurately graduated glass thermometers with lower end of stem as long as possible.

3 soil thermometers-one 3-inch, one 6-inch, and one 12-inch.

(These

are desirable but can be dispensed with.)

1 doz. 4-inch glass funnels.

4 doz. 4-oz. beakers $(125$ c. c.), or small glass tumblers.

1 doz. 600 c. c. lipped beakers.

3100 c. c. graduates.

2200 c. c. graduates.

1 doz. $1 \frac{1}{4}$-inch thistle tubes (see Fig. 2).

3 pounds $\frac{3}{8}$-inch glass tubing.

6 glass rods $3-16$ inch by 8 inches long ("stirring rods"). 
1 doz. No, 14 corks.

6 do\%. 4-0\%. screw cap jars.

6 doz. $\frac{7}{5}$-inch by 5 -inch serew cap homeos.

5 pounis paraffin.

1 set of tools-?ammer, saw; pliers, nippers, scissors ete.

There shomlal be kept in stock two or three bushel lots of at least four limels of soil - "lity, loan, sandy soil, and muck soil, and also coarse samd and fine rimul, all of which should be air tried and carefully screened. In screening these soils a fine meal sieve may be used.

\section{PRETIMINARY FXERCISE.}

1. Ifare each pupil bring in quart samples of as many distinct kinds of soil as can be fomml. Samples should be obtainerl by digging a hole having perpendicular wallis, to the depth of the plowed soil, or in virgin soil to the depth of the soil yroper as indieated by the darker color due to the presence of a larger amomt of organic matter in the soil. In murk soils take s:miples to the depth of six inches. Mix thoronghly the sample snil taken from the $k_{i}$ ole before taking the quart sample.

2. Fach cuart sample should be thoroughly air dried, after which all samples should he examined and grouper on the basis of color, the proportions of (oatres and fine material making w) the sample, and the general mellowness of the sample.

There should the at least four general groms found in most localities - clay. loam, sandy soil and mack. If all of these camnot be fombl in a locality, those lacking shovid be secured from other localities.

3. Characteristic samples of these groups of soils should be preserved in

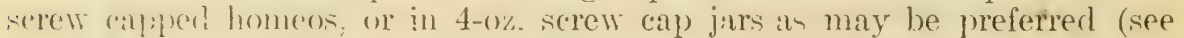
(1 and o Fig. 3). There simples shoukd be saved for future reference and comparison.

1. It woukl be interesting to have pupils bring in guart samples of the first six indhes of the sub-soil corresponting to the soils they bring. These subsoils should he examined and groupes in the sume manner as the soils.

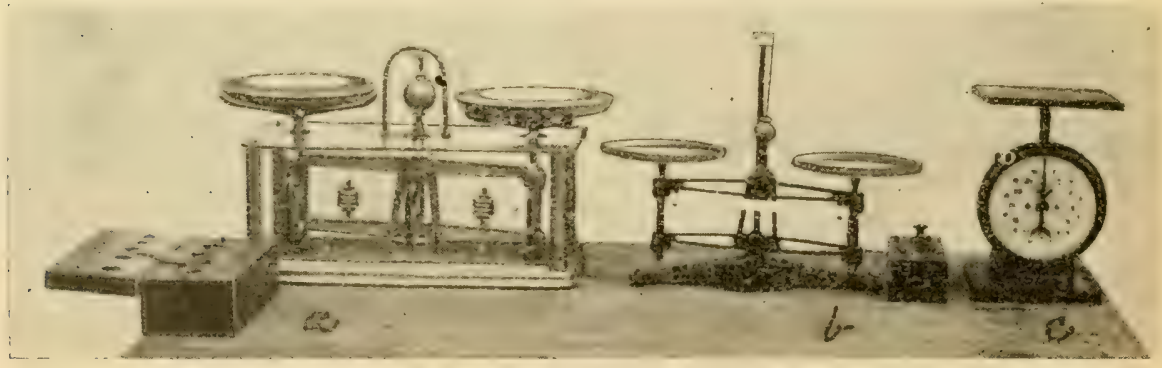

Fig. 1. $a$ and $b$, two styles of torsion balance with accompanying weights, $c$; a common form of kitchen balance weighing to 24 pounds by ounces. 


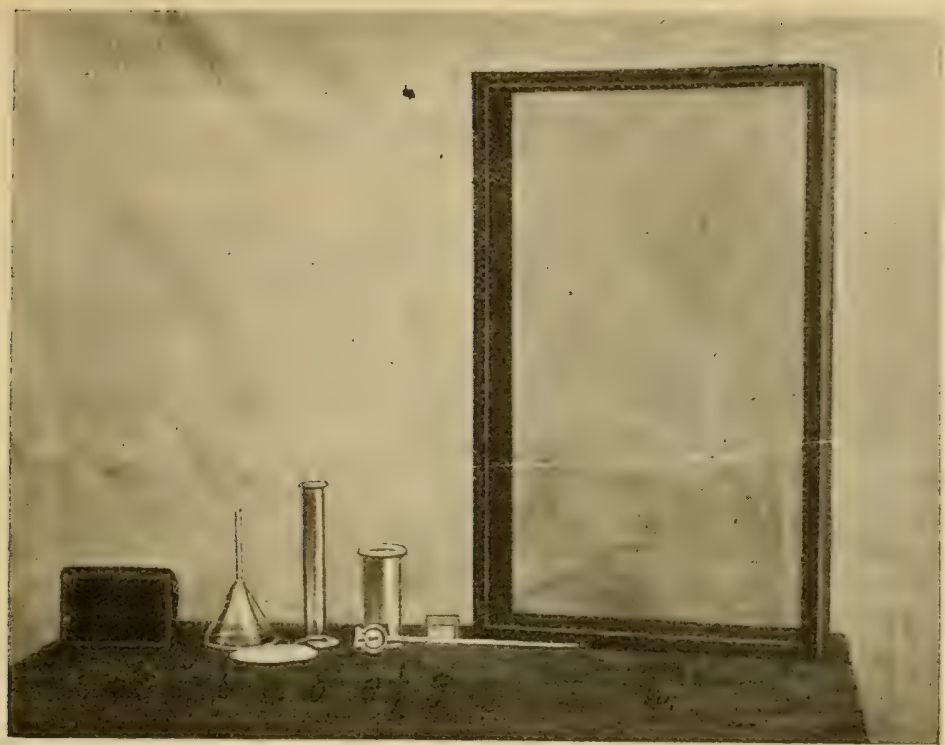

Fig. 2. Here are shown from left to right a cake of paraffin, funnel, filter paper, graduate cylinder, beaker, thistle-tube fummel, box of labels and soil sieve.

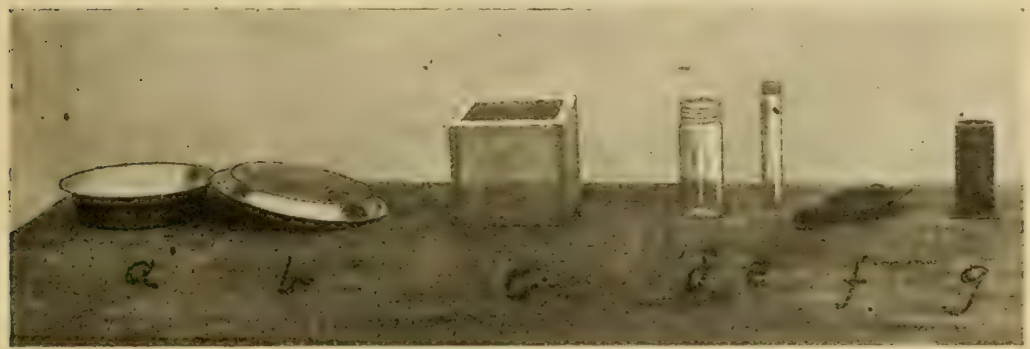

FrG. 3. $a$, quart bean pan; $b$, pie tin for cover; $c$, wooden soil box; $d$, 4-oz. screwcap jar; $e$, screw-cap homeo; $f$, soil scoop; $g$, brass soil tube.

Expertment I.

\section{Pore Space in Soil.-Artificial.}

Apparatus necded:

1 deep metallic vessel ranging in capacity from $\frac{1}{3}$ pint to 1 pint. It may. be made by melting off the open end of a can in which canned com or peas are purchased, or it may be made by soldering a piece of sheet loras: over" one end of a piece of brass pipe $1 \frac{1}{2}$ inches in diameter and 4 inches long (see $g$ Fig. 3). Call these soil tubes.

1 round tamper of wood or one of cork having a glass or wool handie.

1 small piece of wood 12 inches long and $\frac{1}{2}$-inch square.

1 vessel of one pint capacity.

1 balance or seale.

1 sample each of sandy, loamy, and muck soil. 
Before beginning the experiment, opinions may be called for as to how compact a mass of soil may be, as to how much unoceupied space may occur between the particles of soil in the mass with reasons for believing there is or is not any such unoccupied space.

\section{The experiment:}

1. Weigh an empty soil tube and record its weight.

2. Fill this soil tube with water till cven with the top; weigh and record weight.

3. Empty and thoroughly dry this soil tube.

4. Now fill with one of the soils-say the sandy soil. To do this fill the twhe heaping full, hold it firmly upon some solid surface and tap the sides lightly with the small piece of wood mentioned in the list of apparatus. The tapping will cause the soil to settle. See to it that all the while the packing is going on the surface of the soil is kept well rounded by adding more soil. Vary the force of the tapping and do not do all the tapping at one point.

5. When settling of soil ceases, with the straight edge strike off the soil even with the upper edge of the soil tube.

6. Weigh the tube with soil content and record weight.

7. Slowly add water to the soil in the tube until the water ceases to be taken and stands as even with the surface of the soil tube as when the tube was previously filled with water.

Caution: During the adding of the water the sides of the tuhe should be tupped to loosen the air bublles which might cling to the soil walls and so heep out the water.

8. Weigh and record weight.

9. Compute what part of the capacity of the soil tube is filled by soil and what part by water.

What previously occupied the space in the tube now occupied by water? In performing the experiment ise an outline similar to the following:

1. Weight of soil tube full of water

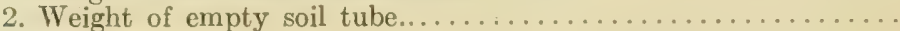

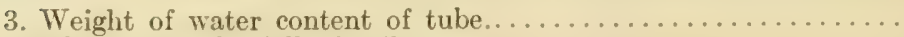

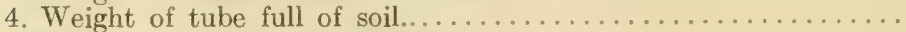

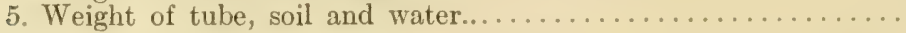

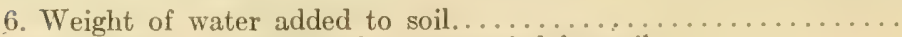

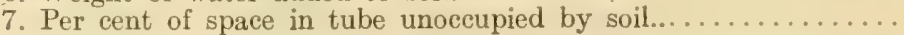

10. Reneat this experiment, using a loam and a muck soil.

Is it desirable that there be pore space in soil? Why?

\section{Experment II.}

\section{Specific Gravity of Soil.}

It is often desired to know the weight of a volume of soil (not including pore space) as compared with a like volume of water. This relative weight is known as specific gravity.

Tsing the necessary weights from the table you filled out in Experiment I fill out the following table: 
1. Weight of water required to fill soil tube (3) $\ldots \ldots \ldots \ldots \ldots$

2. Weight of water added to fill space in soil (6)

3. Difference.

4. Weight of tube and soil content

5. Weight of empty soil tube.

6. Weight of soil in tube...

7. Select from these figures the weight of the volume of water equal to the volume of the soil used in the tube.

8. Determine and indicate the relative weight of the soil as compared with that of the equal volume of water, which is the-

Sipecific gravity of the soil.

9. Determine the specific gravity of at least two different soils.

EXPERIMENT III.

\section{Pore Space in Soil.-Natural.}

Apparutus and material needed:

A spatula or old sharp case knife.

2 pieces of window glass $S$ inches $\times 10$ inches.

1 pound paraffin.

1 quart pan in which to melt the paraffin.

1 two-quart pan.

1250 c. c. beaker.

A strip of card board 3 ? inches by 14 inches.

A piece of the same card board $3 \frac{1}{2}$ inches square.

\section{The expcriment:}

1. From some convenicnt field or sintelen area cut a cube of soil of approximately 4-inch face. Lay on a board or other smooth surface and convey to laboratory.

2. Plare this cube upon one of its faces and with the spatula or knife true one of the perpendicular faces; then cut away and tine the opposite face so that the thickness of the soil between these trued faces shall be about three inches. (It is suggested that the face first trued be the nupler face as it was taken from the field.)

3. Turn the block of soil upon one of the pieces of glass with the surface first trued down.

4. Now cut down and true the remaining four faces so that cach dimension shall be about 3 inches. See Fig. 4 .

5. Slightly round all the edges excepting those resting against the giass.

6. Crease the cardboard strip at distances of $3 \frac{1}{2}$ inches as shown in Fig. 4. Then bend and fasten the ends with a strip of paper and mucilage.

7. Place the case of paper over the cube of soil as shown in Fig. 5, so that the walls of the case shall be about $\frac{1}{4}$-inch in all places from the walls of the cube of soil. Pack some loose soil about the lower outwide edges of the paper case. See Fig. 5.

S. Melt about one pound of the paraffin and allow it to cool until its temperature is just above the melting point.

9. Slowly pour the melted paraffin into the papei case abont the soil until the paraffin stands even with the top of the paper casc.

10. Place the remaining piece of cardboard upon the surface of the melterl paraffin in paper case and allow paraffin to cool. See Fig. 6. 


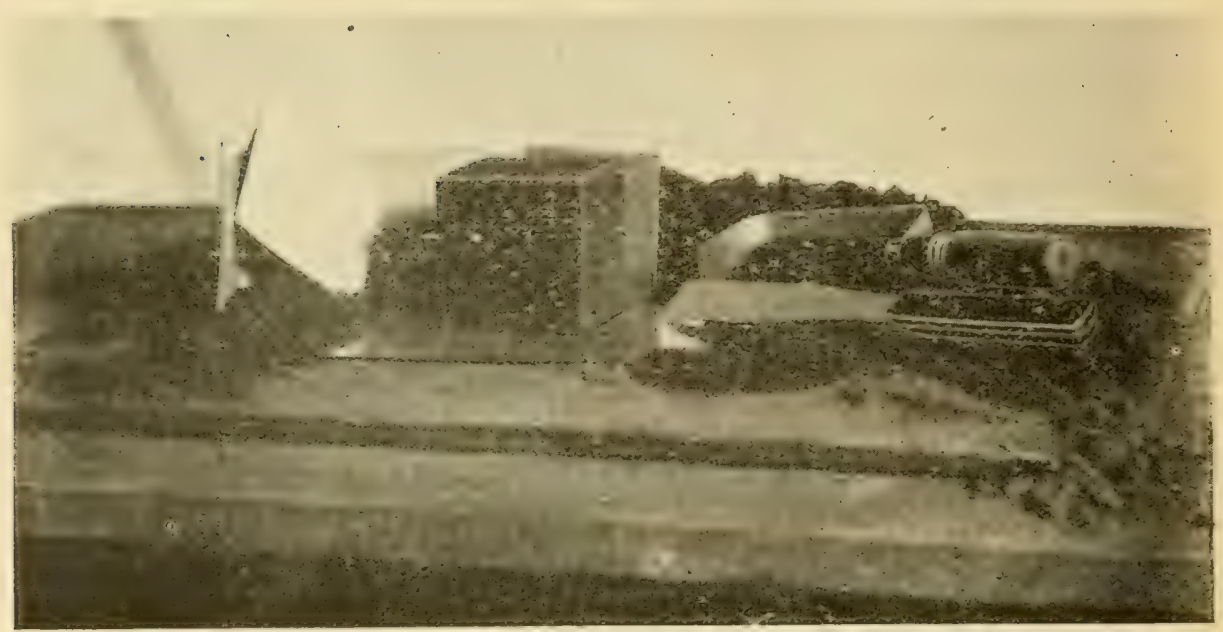

Fig. 4. Cube of soil ready to be encased, and the card board to be lised for the ouler case, with spatula, weeder and loose soil.

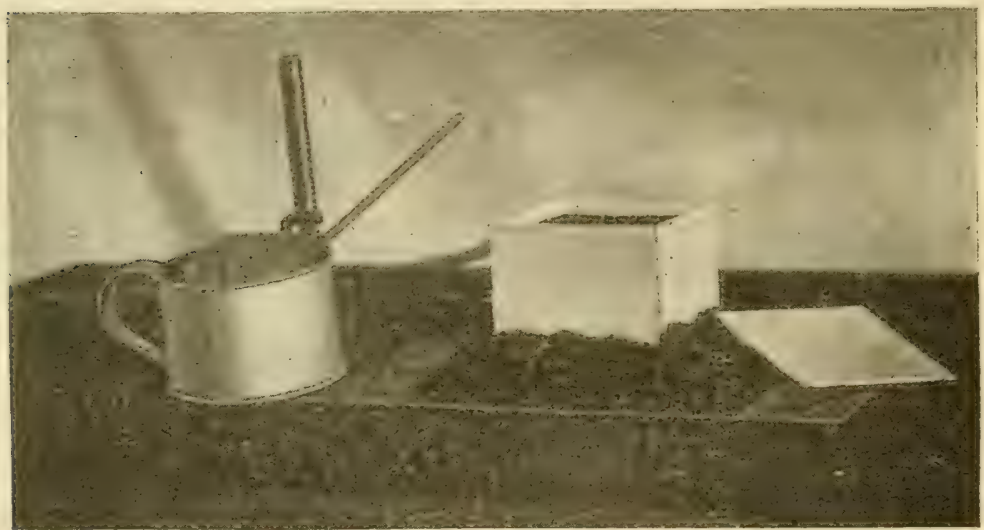

Fig. 5. The for outer case, tin cup, bunsen burner, and glass stirring rod.

11. After a few hours loosen the paraffin case from the glass. (This can warlly be done by furning the case over so that the glass will be up, and tapping the glase lightly. Otherwise pour a little hot water upon the glass.) See Fig. 7.

12. With a one-eighth inch glass or wooden rod make a hole 23 inches l(e+e) near the center of the soil.

13. Pour water very slowly into this hole until the openings in the soil are thromehly filled and the rater stanch even with the top of the soil.

14. With a glass ror or other dull tool remove to the two-quart pan as much of the content of the paper paraffin case as you can without marring the inner surface of the case. 


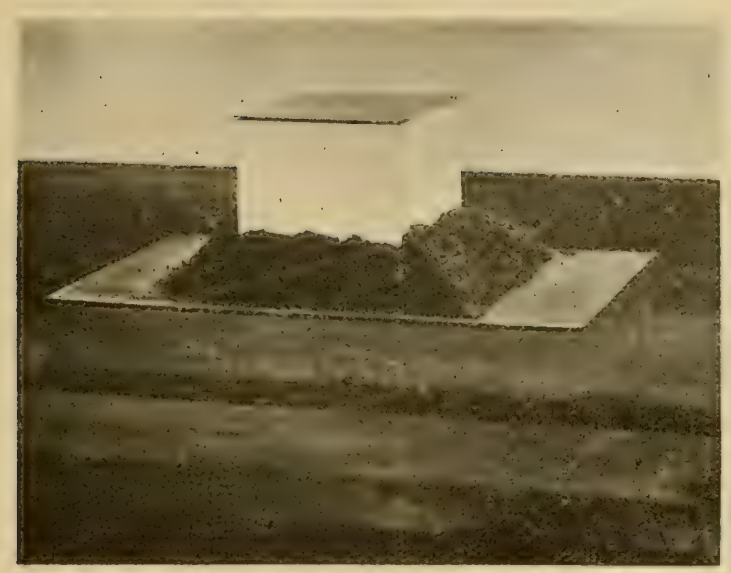

FiG. 6. The encasing of the soil is here completed.

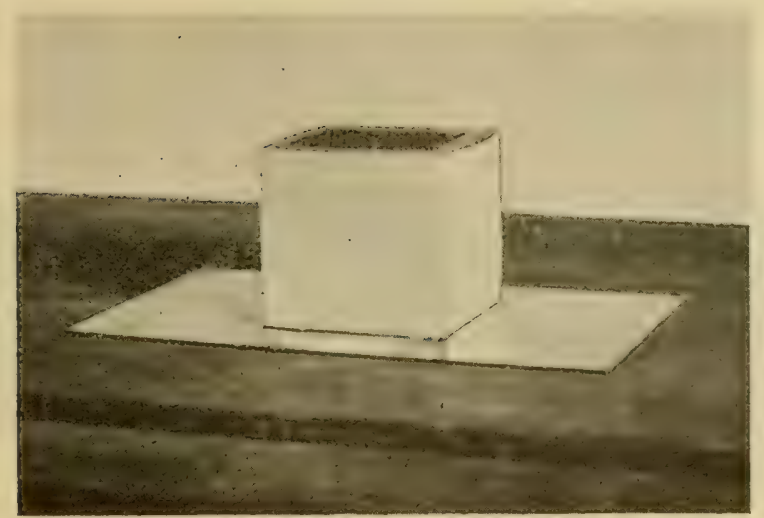

Fig. 7. The encased cube of soil loosened from the glass and placed right side up upon the glass plate.

15. Neasure into a beaker 200 grams (c. c.) of water, and with this wash the remaining soil in the paper-paraffin case into the two-quart pan. I'se all of the 200 grams of water.

16. Weigh the two-quart pan and contents and record the weight.

17. Place the two-quart pan in a drying oven having a temperature of $212^{\circ}$ to $225^{\circ} \mathrm{F}$. $\left(100^{\circ}\right.$ to $110^{\circ} \mathrm{C}$.) until it ceases to lose weight.

1S. Weigh the pan with dry content and record weight.

-19. Weigh the paper-paraffin case, empty, and record weight. 20. Fill the case even full of water, weigh and record weight. Use a table something like the following: 
Weight of paper-paraffin case full of water.

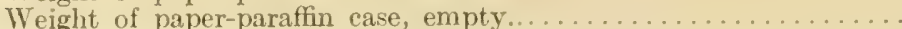

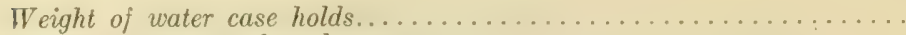

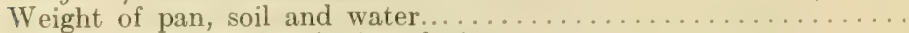

Weight of pan and soil after drying.

Weight of water lost in drying. .

Weight of water used in washing.

Weight of water in saturated soil in case.

Ising the weight of rater whirh the payer-paraftin ease holels and the water contained in the saturated soil iri the ense, estimate the amomnt of pore space in the soil in the case.

TXPFIRMENT IT.

\section{Weight of Soils under Artificial Conditions.}

A pparatus and materinl needed:

A box of woorl or metal 4 inches in encl: dimension, open on one side. Call it a soil box. (Fig. 2.)

A small nallet or a piece of wood 12 inches long and $\frac{1}{2}$-inch square.

A straight edge of some sort.

3 pints each of say, four soils-a sandy soil, a loam soil, a clay soil, and a muck soil, all air-dry.

\section{The experiment:}

-1. Weigh soil box and record weight.

2. Fill the soil box heaping full with the sandy soil and settle as completely as possible by tapping the sides of the soil box with the mallet or stick.

('untion: Hold the box firm?y upon some soltit surface while tapping and set' In it that soil is added from iime to time to ?.erp the surface of soil in the box well rounded all the while. Vary the force of the tapping.

$\therefore$. When the soil ceases to settle strike ofit the surface of soil even with top of box.

4. Weigh the box with its contents and record weight.

5. Determine the weight of soil in box.

6. Estimate the weight of a cubic font of stich soil.

Use a form like the following:

1. Weight of soil box and soil content.

2. Weight of soil box..

3. Weight of soil in box.

4. Estimated weight of a cubic foot of this soil.

\section{Alternate.}

The above experiment inay be performed by using a tin pea or corn can with the open end melted off.

In msing such a can its capreity should be determined as follows:

1. Weigh the can empty and record weight.

2. Fill the can with water.

3. Weigh the can full of water and record weight.

4. Subtracting the weight of the cmpty an from the weight of the ean 
filled with water gives the weight of the rolume of water which the can holds. One eu. inch of water weighs $.036 \mathrm{lbs}$. or 16.33 grams.

5. Having the weight of the water which the can holds, estimate its capacity. Use a form like the following:

1. Weight of can full of water..

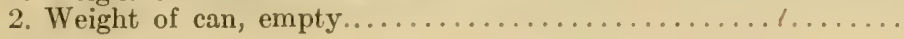

Weight of water in can..

3. Estimated volume of water in can in cubic inches............

From this point proceed as in soil-box experiment.

Can you plan and execute an cxperiment by which you can determine the wiyht per cubic foot of field soils-soil under natural conditions?

Experiment $V$.

\section{Water-holding Power of Soils.-Artificial.}

Apparatus and materials needed:

8 four-inch glass funnels.

1 package of 6 -inch filter papers.

1 rack for carrying the eight funnels. (This rack may be made of a board 1 inch $\times 6$ inches -5 feet long, with eight three-inch holes bored at distances of 7 inches apart center to center. The holes may be bored with an extension bit. When in use let this rack rest on supports six to eight inches high.). See Fig. 8.

8 four-ounce beakers or ordinary glass tumblers.

1100 c. c. graduate eylinder.

4 lots of air-dry soil--a sandy soil, a loamy soil, a clay soil and a muck soil.

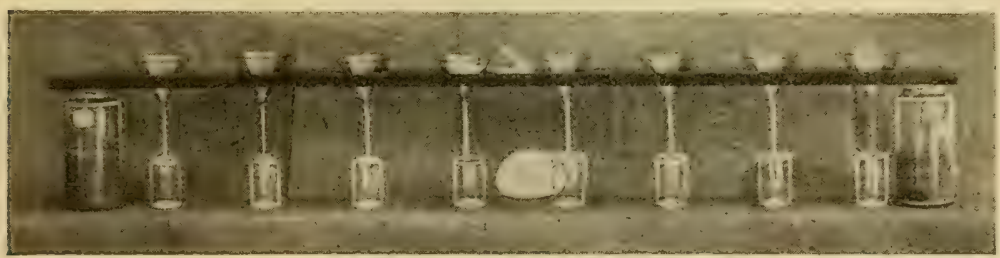

FiG. 8. Funnels in place in simple wooden rack witl beakers under the funnels in experiment to study water-holding power of soils.

The experiment:

1. Mount the eight funnels in the rack.

2. Fold a filter paper for each funnel, set in place and wet so that it will stay in place.

3. Weigh out and introduce into each of two funnels 100 grams of the sandy soil.

4. Weigh out and introduce into each of two other funnels 100 grams of the clay soil.

5. Weigh out and introduce into each of two other funiels 100 grams of loamy soil.

6. Weigh out and introduce into each of the two remaining funnels 50 grams of the muck soil.

7. Place a beaker under each funnel. 
५. Measure 100 c.c. of water into each of the funnels containing the saridy, clay, and loamy soils.

9. Veasure 150 c. c. of water into cacle of the funnels containing the muck soils.

10. When the water has ceaserl to cirain into the beakers from all the soils measure and record the amount of water that has drained from ench soil.

What does a $c$. c. of water weigh?

Introduce data into at table like the following:

Water-holding Capacity of Soils.

\begin{tabular}{|c|c|c|c|c|c|c|c|}
\hline No. & $\begin{array}{l}\text { Kind } \\
\text { of } \\
\text { soil. }\end{array}$ & $\begin{array}{c}\text { Weight } \\
\text { of } \\
\text { soil. }\end{array}$ & $\begin{array}{l}\text { Water } \\
\text { added. }\end{array}$ & $\begin{array}{l}\text { Water } \\
\text { recovered }\end{array}$ & $\begin{array}{l}\text { Waier } \\
\text { retained } \\
\text { by soil. }\end{array}$ & $\begin{array}{l}\text { Average } \\
\text { amount } \\
\text { of water } \\
\text { retained } \\
\text { by soil. }\end{array}$ & $\begin{array}{l}\% \text { of } \\
\text { water } \\
\text { retained. }\end{array}$ \\
\hline & $\begin{array}{l}\text { Sandy. } \\
\text { Sandly.. }\end{array}$ & & & & & & \\
\hline 3 & $\begin{array}{l}\text { (lay } \ldots . . . \\
\text { ("lay.... }\end{array}$ & . & & & & & \\
\hline i). & $\begin{array}{l}\text { L.oam. . } \\
\text { Loam. }\end{array}$ & & & $\ldots \ldots$ & & & $\ldots \ldots \ldots$ \\
\hline & $\begin{array}{l}\text { Muck.. } \\
\text { Muck.. }\end{array}$ & & & & & & \\
\hline
\end{tabular}

11. Remember that in computing the per cent of water retained hy the soil, the weight of dry soil is used as the base.

1:. Account for the differenres in the amounts of water retained by the sand and the day; the and and the mick; the sand and the loam.

Experming VI.

\section{Water-holding Power of Soils as Affected by Presence of Organic Matter.}

1. Repert Experiment $Y$, using mistures of sand and muck as follows: (!) 1ll sand and no munk, (2) 80\% sanil and ?0\% nuck, (3) $60 \%$ sand mu! for, murk, and (4) for, sand and $60 \%$ muck.

2. Acomint for the rlifferences in the percentage amount of water retained by the different combinations of sand and muck.

3. To the perentage :monuts of water retained by the different conibinations leagr any relation to the amomints of muck or sund in the combinations?

\section{Faptiminent ViI.}

\section{Water-holding Power of Soils as Affected by Amount of Clay Present.}

1. Peepeat Experinent $Y$, uing conbinations of sand and rlay as follows: (1) $100 \%$ of sand, (2) $80 \%$ of sand and $20 \%$ of clay, (3) $60 \%$ of sand and $40 \%$ of clay, mel (4) $40 \%$ of sand and $60 \%$ clay. 
2. Account for the differences in the percentage amutints of water retained by the different combinations.

3. Do the percentage amuunts of water retained by the different combinations of sand and clay bear any relation to the amounts of clay or sand in the conibinations?

Typeriment VIII.

\section{Water in Soils under Natural Conditions.}

Apparatus needed:

A sharp spade.

3 nne-quart bean or pudding pans.

3 eight-inch pie tins to be used as covers for the pans.

'The pans and pie tins should be permanently numbered.

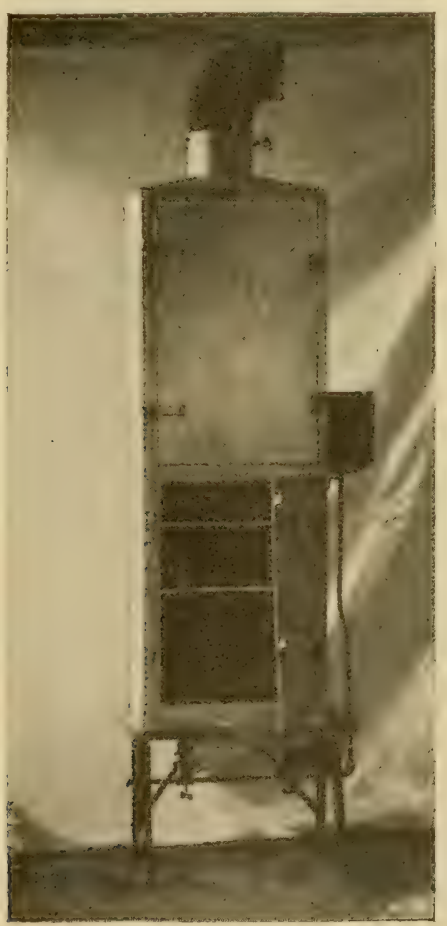

FIG, 9. Galvanized iron drying oven in place upon an ordinary two-burner gasoline stove. This oven is 17 inches wide $\times 13$ inches deep $x 48$ inches high.

\section{The experinient:}

1. At a point in a field or garden where the nodisture conditions seem good for growing a crop, lig with the sjmle to the depth of the soil-five inches to eight inches. On one side of the hole have the wall perpendic lar, and remove all loose soil from: the bottom of the hole. 
2. With the spacle cut off, from top to bottom, about one inch of the face of the perpendicular wall, allowing the soil to fall to the bottom of the hole.

3. As quickly as possible, thoroughly mix the soil so cut from the wall; fill one of the pans two-thirds full with the mixed soil and cover with a pie tin.

4. Move off a short clistance, dig another hole and take another samp!e in the same manner, placing the sample in another pan.

$\therefore$ Mne to a third place and take a third sample, placing it in another pan.

(i. On arriving at the laboratory weigh each pan with its contents, recorcling the number and weight in each case.

7. The pans with their contents should now be subjected to a temprerature of $212^{\circ}$ to $225^{\circ} \mathrm{F}$. until the pans ccase to lose weight. This will require from $S$ hours to 16 hours, depending ujun the soil. See Fig. 9.

8. When dry, weigh each pan with its contents and record.

9. Remove the dry soil from each pan, weigh the pan and record.

10. Determine the per cent of moisture in each soil.

Use a form like the following:

Natural Water Content of Soils.

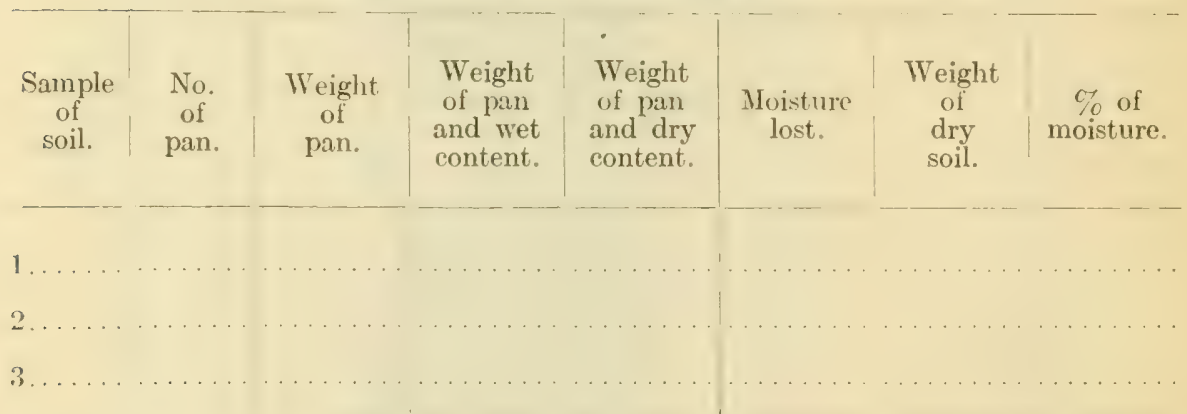

The per acnt of moisture in soil is found by dividing the weight of moisture lust by the weight of dry soil.

EXPFITMLNT IX.

\section{Water in Soil When Plants Cease to Grow. A-Under Natural Conditions.}

Apparatus needed:

Same as those required in Experiment VIII.

The experiment:

1. Where it is possible, select an arca where plants are suffering from drought, that is, where a drought has continued till field plants have begun to turn yellow or to wilt badly, and determine the inoisture content of the soil, proceeding in every particular as in experiment VIIT.

Use a table like that in Experiment VIII. 


\section{Alternate. B-Under Artificial Conditions.}

Where field conditions are not found as above, the work may be done under artificial conditions.

\section{Apparatus needed:}

1 deep gallon jar.

2 onc-quart pans with pie tins for covers.

A few kernels of good seed corn or oats.

A gallon of field soil in good tilth and moisture condition.

\section{The experiment:}

1. Fill the jar to within a half-inch of the lop with the soil, packing lightly. Be sure that the soil is in about the right condition of moisture for plowing or for being planted to seed.

2. At the time of filling the jar, take two samples of the soils in pans and determine the moisture contained.

3. Weigh the jar and soil content and record weight.

4. Plant six kernels of oats or three kernels of corn three-fourths inch deep in the soil in the jar. After they have germinated, thin to four plants of oats or two plants of corn.

5. Until the oats are eight inches high or the corn plants are twelve inches high, weigh the jar once each week and add water enough to bring the weight up to the original weight, recording the same in each case.

6. When the urop has reached the height indicated above, allow the jar to stand until the plants show decided effects of lack of moisture.

7. Weigh jar and contents and record weight.

S. Remove the crop, then remove the soil from the jar; thoroughly mix, and sift a portion through a coarse sieve to remove roots.

9. Take two samples of this sifted soil and determine moisture content, as in Experiment VIII.

The preparation of the soil and the taking of samples stinuld be done without undue loss of time.

Use a table something like this:

Water in Soil When Plants Cease to Grow.

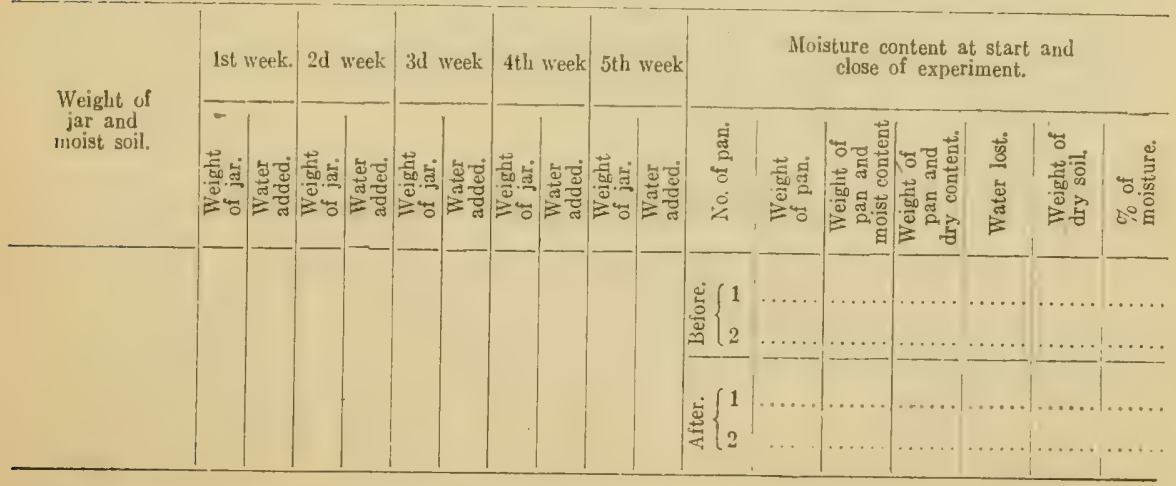

It would be worth while to use two soils for experiment $\mathrm{B}-\mathrm{a}$ rather heavy soil and a light soil. 


\section{EXPERMENT $\mathrm{X}$.}

\section{Moisture in Air-dry Soil.}

Apparatus and materials needed:

4 two-quart pans.

4 soils - a sandy soil, a loamy soil, a clay soil, and a muck soil-all airdry. It would be well to let all these lots of soil stand together in an open room for a few days before using in this experiment.

If all these soils are not available use as many as can be secured.

\section{The experiment:}

1. Carefully number and weigh 4 pans and record their weights.

2. Into three pans weigh 1000 grams of sathdy woil, of loamy soil, and clay woil respectively, and into the fourth pan weigh 500 grams of the muck soil.

3. Subject the pans and contents to a temperature of $212^{\circ}$ to $225^{\circ} \mathrm{F}$, or $100^{\circ}$ to $110^{\circ} \mathrm{C}$. until they cease to lose weight.

4. Weigh pans and dry contents and record weights.

Use a table like the following:

\section{Moisture in Air-dry Soils.}

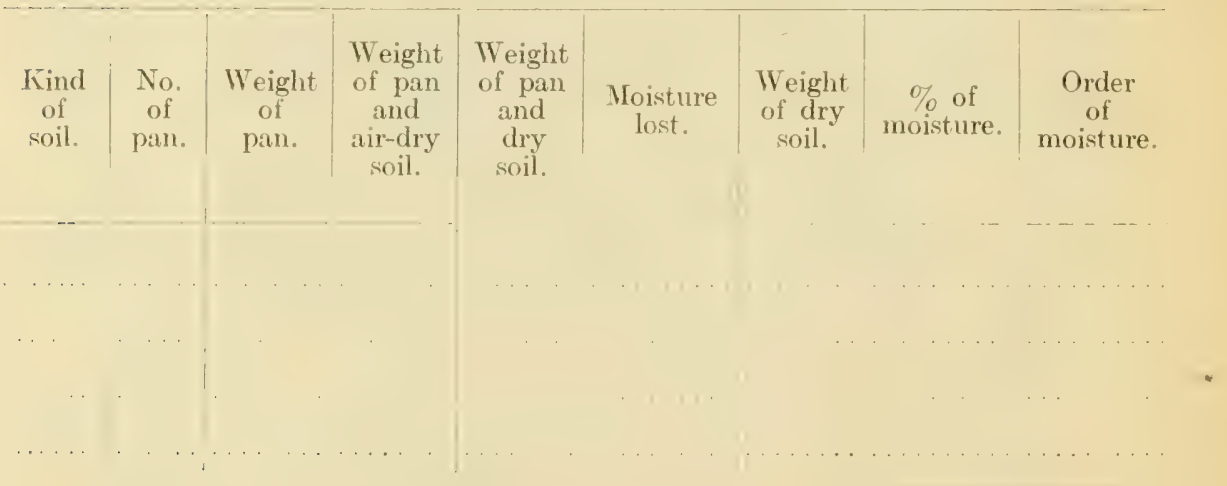

Offer any good reasons that may occur to you for any differences that may have been found.

Experiment XI.

\section{Moisture Losses from Cultivated and Uncultivated Soil Surfaces.}

(Read directions for Experiment XII before performing this one.)

Apparatus and materials needed:

6 deep one gallon jars.

1 straight edge.

1 lipped beaker.

A gauge (see Fig. 10).

A four-quart pan.

A small scoop.

A quart cup. 


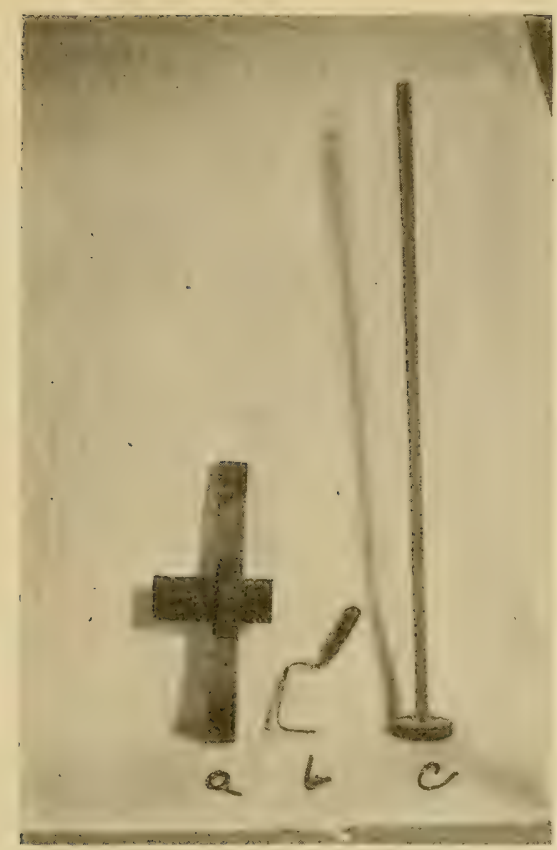

Fia. 10. $a$, gauge for removing soil from jars in cultivation experiment. $b$, common garden weeder. $c$, simple wooden tmimer that may bo used in compacting soil in boxes or jars.

(i pieces three-eighths inch glass tubing of o wass thistle tube fumnels. (The glass tubes or the fummel stems should be one inch longer than the height of the jars.)

1! bushels of good field soil, preferably a sandy loam. (This soil should be screened to remove large pebbles and coarse materials, and shomld be in good moisture condition for plowing or cropping.)

1 gallon of very coarse sand.

\section{lixperiment:}

1. Thoroughly mix the one and a half bushels of soil. Be sure the condition of moisture is right. If too dry add water during the mixing. Shovel into a compact heap.

2. Number the six jars 1 to 6 and place them in order near the heap of soil.

3. Place in the bottom of each jar one pint of the coarse sand, spreading evenly over the bottom.

4. Place a piece of the glass tubing or a funnel in each jar, against the side of the jar, and with the lower end resting on the sand. A piece of light wire properly bent over the edge of the jar will hold the tubing or funnel in place during the filling.

5. Add a struck-off cup of soil to jar number 1, then one to number 2 , and so on till each jar has received one quart of soil. Fipread out the soil in each jar and pack firmly with the hand or with the bottom of the cup, being careful to treat the soil in the six jars, uniformly. 
6. Repeat the atdition and packing of soil described in 5 mutil each jar is rounding full.

7. When the jars have been thus filled, strike off each surfare even with the rim of the jar, using a straight-edge.

S. Set jars number 1 and number 6 to one side.

9. Set the gauge so that the blade shall extend one inch below the edge of woor frame and with gauge and scoop remove the soil from the surface of number '2 and number 5 to the repth of one inch, placing the soil in the pan. Thoroughly crumble with the hands the soil thus removed and return to the jars. This will fill the jars rounding full again. 'Tap lightly. Then with straight-edge strike off each surfare even with rim of jar. Carefully set jars 2 and 5 aside.

10. Set the gauge so that the blade shall extend two inches below edge of wooden frame, and with gauge and scoop remove the soil from surface of jars number 3 and number 4 to the depth of two inches, placing the soil in the pan. Thoroughly mix and return to jars, tap jars and strike off as in 9 .

Note-Observe that we have secured in jars $2,5,3$ and 4 what we secure in the field by cultivating one inch and two inches deep respectively. In the jars, however, we have secured much greater uniformity of both depth and stirring of soil.

11. Add $\frac{1}{2}$ pound of water to each jar through the tube or funnel.

12. Weigh and record weight of each jar in order. (See Fig. 11.)

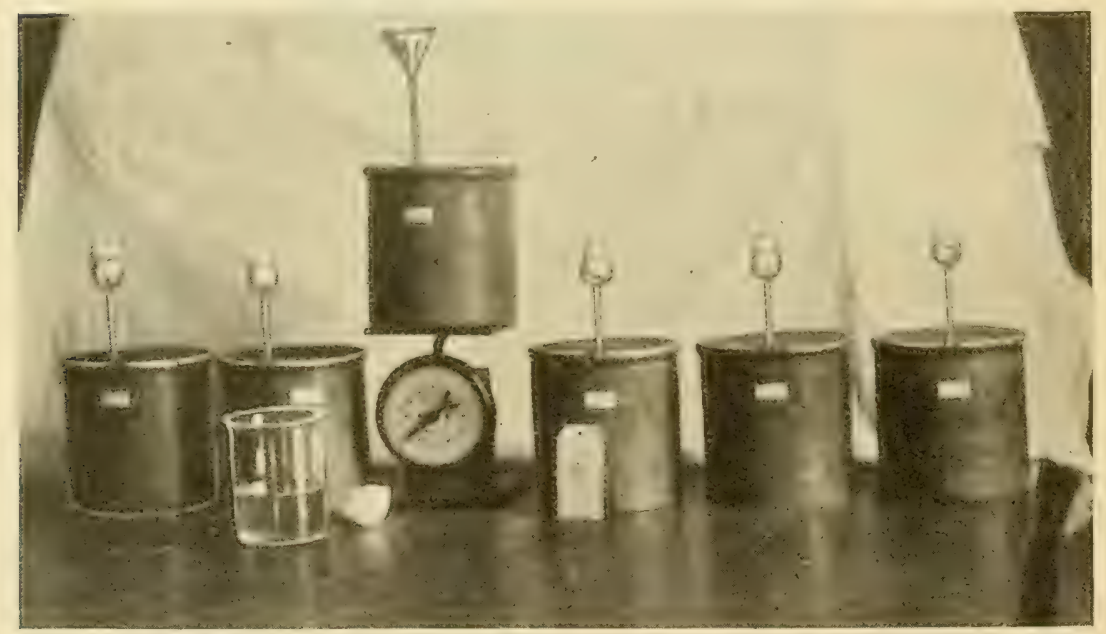

Frg. 11. Showing jars as they appear when filled in Experiment $\mathbf{X I}$. One of the jars rests upon platform of the kitchen balance.

13. Place the six jars in order in some place sufficiently sheltered to protect from rains and birds.

14. At the end of one week weigh each jar, record weight and add water through the tube or funnel sufficient to bring the jar and contents up to the original weight.

Note-To bring up to weight leave the jar on scale and add water through tube or funnel very slowly.

15. Repeat 14 at the end of the 2nd, 3rd; 4th, and 5th weeks.

16. Determine the total loss by evaporation from each jar. 
17. Compare the individual losses.

18. Average the losses of duplicates - 1 and 6,2 and 5, and 3 and 4 , and compare the averages.

19. Using the averages obtained in 18, determine the losses per day per acre, with no cultivation, one inch of cultivation, and two inches of cultivation.

Table of Moisture Losses from Cultivated Soils.

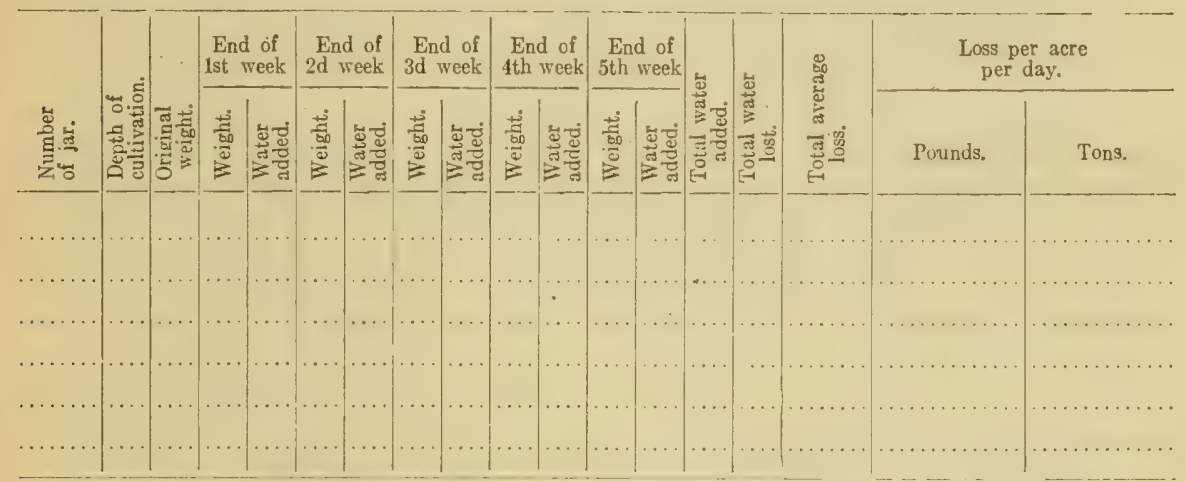

20. Account for differences in average losses.

What does the experiment teach?

\section{EXPERIMENT XII.}

\section{Effect of Dry-earth Mulches upon Moisture Losses.}

Apparatus and materials needed:

6 deep one-gallon jars.

1 straight-edge.

1 gauge.

1 small scoop.

1 lipped beaker or cylinder ( 8 oz. or 250 c. c.)

1 four-quart pan.

1 quart cup.

6 pieces $\frac{3}{8}$-inch tubing of 6 thistle-tube funnels as described in Experiment XI.

$1 \frac{1}{2}$ bushels of good field soil, preferably a sandy loam, as described in Experiment XI.

1 gallon of the same soil thoroughly air-dryed.

1 gallon very coarse sand.

The experiment:

1. Fill the six jars with soil, carefully following directions 1 to 8 in Experiment XI.

2. With scoop and gauge carefully remove the surface soil from jars 2 and 5 to the depth of one inch. Do not return soil.

3. With scoop and gauge carefully remove the surface soil from jars 3 and 4 to the depth of two inches. Do not return soil.

4. Introduce into jars $2,5,3$, and 4 to rounding full the air-dry soil, tap lightly, and with straight-edge strike off surfaces even with rim of jars. 
5. Adrl eight ounces of water to each of the six jars through tube or fumel.

6. Weigh each jar and record weight.

7. At the end of each weck, for five wreks, wrigh earh jar, record weight. and atcl slowly sufficient, water to hring weight wy to the original weight as in Experiment XI.

S. Determine the total loss for each pan.

9. Compare losses.

10. Average the losses of the duplicate jars, 1 and 6 , 2 and is, and :3 and t, and compare.

11. Estimate the losses per day per acre, using averages only.

Use a table similar to that in Experiment XI.

suggest any practioal application of the knowlerlge ganed from this experiment.

It would he well io perform this experiment. in comection with Experiment XI, in which ase jars 1 and 6 of this experiment entel be omitted. With slight changes, too, one table could be made to hold all data.

\section{Experiment XIII.}

The Effect of Water in the Puddling or Baking of Soils.

Apporatus and materiuls necded:

4 coffee cups, or 4 3-inch evaporating dishes.

4 one-pint lots of the following soils, well moistened-a sandy soil, a loam, a clay soil, and a muck soil.

\section{The experiment:}

1. Weigh out 30 grams each of the satuly soil, the loan and the clay soil ancl 15 grams of the muck soil. placeing earh weighed lot in a separate cup or dish.

2. Introluce into each ("np) or clish sufficient water to slightly more than completely cover the soil in it.

3. Place the cup or dishes with their contents in a warm dry place and allow to stand until all the water has evaporated and the remaining soil appears to be thoroughly dry.

4. After this drying is complete cximine these soils and note any differences in the compactness of the masses.

5. Account for these differences.

Perhaps you may be able to measure in a cluantitative way the firmmess of these dry masses of soil.

Have you ever observed as complete comparting of the surface soil in a corn field?

Can you explain how a young corn plant may reach the surface of a soil in such condition?

Suggest some means of preventing the puddling of soils.

\section{EXPERIMENT XIV.}

\section{Effect of Organic Matter in Soil upon the Degree of Puddling or Baking.}

A pparatus and material needed:

5 coffee cups or 5 -inch evaporating dishes.

2 one-quart lots of air-dry soil, one of clay and one of muck.

1600 c. c. beaker or graduate. 
The experiment:

1. Into the five cups or the five dishes introduce soil as follows:

1 st -24 grams of clay.

2nd-18 grams of clay and 6 grams of muck.

3rd-12 grams of clay and 12 grams of muck.

4 th - 6 grams of clay and 18 grams of muck.

5 th-24 grams of muck.

What are the percentage amounts in each case?

2. Mix the contents of cups or dishes 2,3 , and 4 thoroughly.

3. Add slowly to each (up or dish sufficient water to enver the soil onefourth inch.

4. Place cups or dishes and contents in a warm dry place, and allow to stand until thoroughly dry.

5. Note differences in compactness of the drierl masses of soil, and so far as you can, account for the differences.

6. If you can, measure the differences.

7. Do the results of this experiment suggest any method of farm practice?

EXPERTMENT XV.

Effect of Sandy Material in Soil upon the Degree of Puddling.

Apparatus and materials needed:

Same as in last experiment exeept that guart lots of air-try chay and sand are to be used.

\section{The experiment:}

1. Into the five cups or the five dishes introduce soil as follows:

1st -24 grams of clay.

2nd-18 grams of clay and 6 grams of sand.

3rd-12 grams of clay and 12 grams of sand.

4th - 6 grams of clay and 18 grams of sand.

5 th -24 grams of sand.

From this point proceed as in experiment XIV.

\section{SOLI, TEMPERATURE.}

For this work it is desirable, though not absolutely necessary, to have a set of all-glass soil thermometers, one three-inch, one six-inch, ant one twelve-inch. (These can be purchased of Henry Green \& Co., Brooklyn, N. Y.) Whether this set can be afforded or not, there should be provided one dozen accurately graduated all-glass thermometers. For this work Fahrenheit thermometers will probably prove best, and they should be sufficiently long in the lower stem, if possible, to give a length of three inches between the middle of the bulb and the $40^{\circ}$ mark.

With such a set of soil thermometers as that indicated above, the temperature of the soil may be ohserved at depths of 3 inches, 6 inches and 12 inches respectively. With the ordinary thermometers the temperature may be observed at the surface aid ordinarily not more than three inches below the surface. 
To insert the bulb of an all-glass thermometer below the surface of the ground a hole must first be made with an iron or steel rod. If the surface is dry or loose it may be necessary to set a casing of paper or wood about the top of the hole to prevent the loose soil from falling into the hole to interfere with the inserting and removing of the thermometer. The hole should be so made that the center of the thermometer bulb shall stand at the depth at which the temperature is to be observed. After placing the thermometer in the soil it should be allowed to stand from 3 minutes to 5 minutes before reading in order that the mercury may come to rest.

\section{EXPERIMENT XVI.}

\section{A Study of the Variations in Temperature of Natural Field or Garden Soils During the Day at Depths of 0, 3, 6 and 12 inches respectively.}

\section{Apparatus needed:}

1 carefully graduated ordinary thermometer.

3 soil thermometers, 3 -inch, 6-inch and 12-inch.

(See Exp. XVII as alternative.)

1 steel rod for making holes for soil thermometers.

\section{The experiment:}

1. Select some convenient uncropped area in a field or garden.

2. With the iron rod make three holes of proper depth respectively to receive the three soil thermometers, casing the tops with paper or wooden tubes.

(These holes should be about four inches apart in an east and west line.)

3. Place the soil thermometers each in its proper hole, and the ordinary thermometer so that its bulb shall lie flat upon the surface of the ground three inches south of the middle soil thermometer.

4. After five minutes quickly read all the thermometers and record the readings.

5. At intervals of two hours during the day repeat 3 and 4 , taking the first reading as early as sunrise if possible, and the last just before sunset.

Use a table something like the following for recording data:

Soil Temperature.

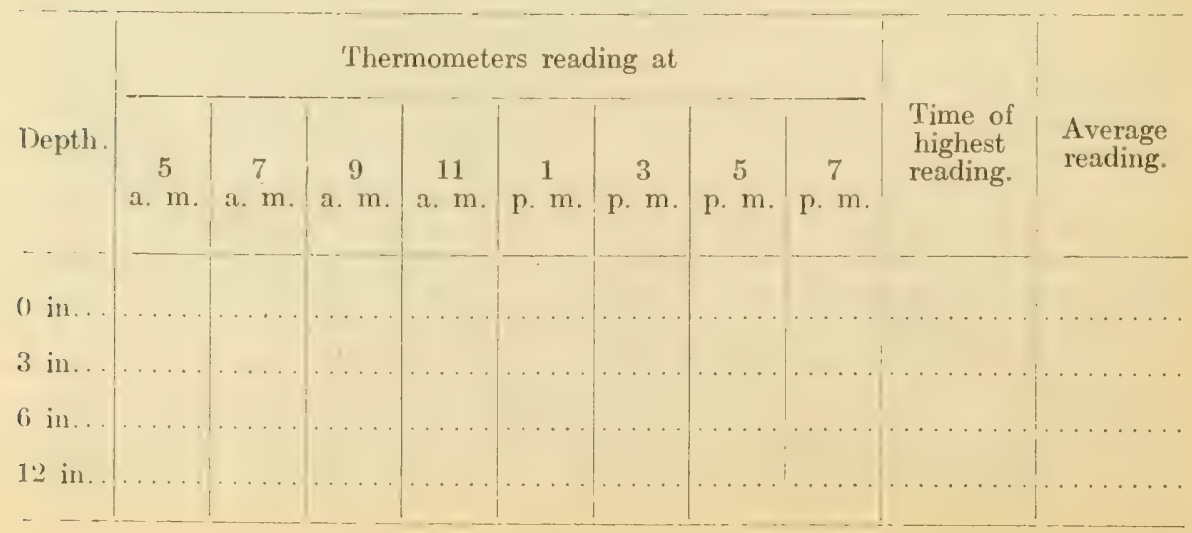


6. Record any conclusions the data obtained may in your opinion warrant.

It would be well to repeat this experiment upon a number of days to note the progression of change, and the effect of clouds, rain, variation of air temperature, etc., upon soil temperatures.

\section{Experiment XVII.}

(To be performed in place of the previous experiment if the laboratory does not possess soil thermometers.)

\section{Apparatus needed:}

2 carefully graduated ordinary all-glass thermometers.

1 iron rod for making holes for the thermometer.

\section{The experiment:}

1. Select some convenient uncropped area in a field or garden.

2. With the iron rod make a hole in the soil deep enough to allow the thermometer to be inserted three inches into the soil, provided that at that depth the $50^{\circ}$ mark on the stem stands above the surface of the soil. Otherwise make the hole deep enough to receive the thermometer so that the $50^{\circ}$ mark on the stem shall stand just above the surface of the soil. Insert the thermometer.

3. Place the other thermometer so that its bulb shall lie flat on the surface of the ground three inches south of the other thermometer.

4. After the thermometers have been in place 5 minutes rearl them and record the readings.

5. Repeat 4 at intervals of two hours during the day, as directed in Experiment XVI.

Use a table similar to that used in Experiment XVI for recording data.

Mention any interesting points which in your opinion the experiment has shown.

It would be well to repeat this experiment upon a number of days to note the progressive changes, the effects of clouds, rains, etr., upon soil temperature.

\section{EXPERIMENT XVIII.}

\section{The Effect of Slope upon the Temperature of the Soil.}

\section{Apparatus needed:}

The same as in Hxperiment XVI if soil thermoneters are available; otherwise the same as in Experiment XVII.

\section{The experiment:}

1. Select two convenient areas, one on a south slope and one on a north slope. Be sure the two areas are alike or nearly so in texture and color of soil.

2. Using one of the methods described above (Experiments XVI and XVII) take and record one set of temperature readings on the south slope.

3. Move the apparatus to the area on the north slope, take and record a set of temperature readings as on the south slope.

Plan to set the thermometers so that the readings on the north slope may 
he taken just 10 minutes after the realings were taken on the south slope.

4. Leave the themometers in place on the north slope and just 10 minutes after the first readings on the north slope reve taken, take and record another set of readings.

5. Remove apparatus to the south slope and take and record a set of rearlings, laking the reartings just 10) minutes after the seend set of readings on the north slope were taken.

(i. Average the two sets of readings taken on the south slope, i. e., average the two surface realings, then average the 3 -inch readings, and so on.

7. Average the two sets of readings taken on the north slope.

Use a table like the following:

The Effect of Slope upon the Temperature of the Soil.

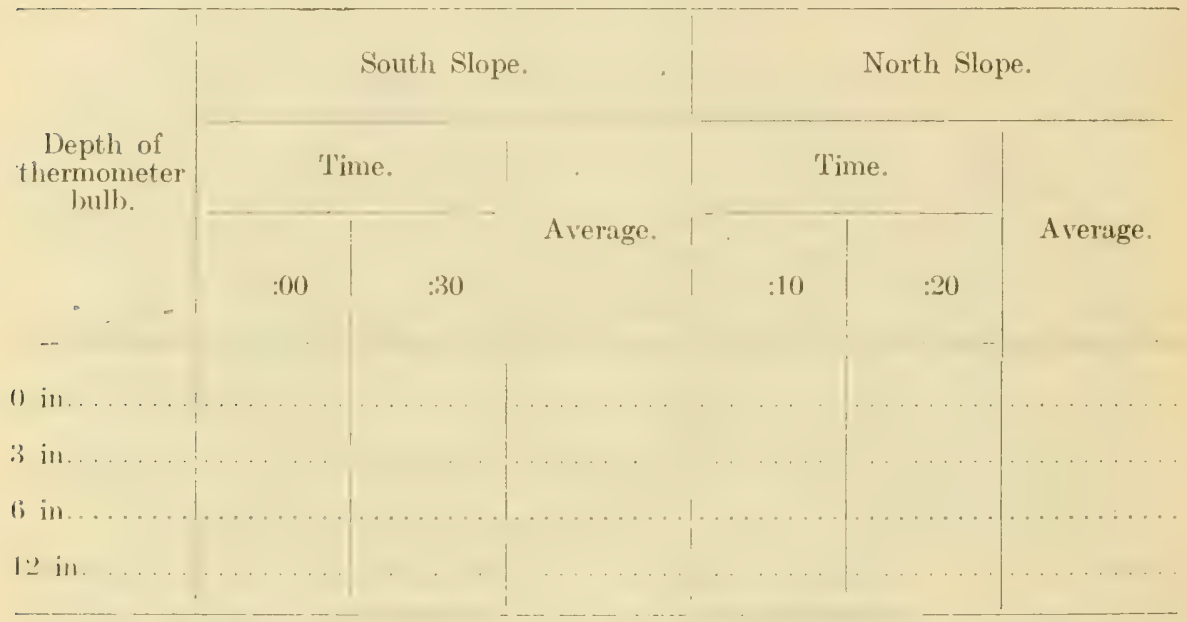

S. Record any conclusions that in your opinion the data obtained warrant.

9. Why time the rearlings as indicated?

GXPERTMENT XTY.

The Effect of Color upon the Temperature of Soil (with air-dry soils and laboratory conditions).

Apparatus and materials needed:

$S$ one-quart pudding or bean pans.

Three pint-lots of the following kinds of soil: light colored loam, dark loam, light colored sandy, all air-clry and sifted.

2 quarts of clay soil, air-dry and sifted.

5 quarts of muck soil, air-dry and sifted.

One-half pint pulverized chalk, slaked lime or plaster of Paris.

1 carefully graduated all-glass thermometer reading to degrees, or better, to half degrees.

7 feet of No. 12 galvanized iron wire, and a perforated No. 14 cork to make a frame to hold the thermometer. 
The experiment:

1. a. Fill one pan with the clay soil.

b. Fill one pan with the light colored loam.

c. Fill one pan with the dark colored loam.

d. Fill one pan with the light sandy soil.

e. Fill one pan with the muck soil.

f. Fill one pan with the clay, leaving room for just enough muck to conpletely cover the surface of the clay.

n. Fill one pan with the muck soil, leaving room for just enough of the fine clay to completely cover the surface.

h. Fill one pan with the muck soil, leaving just room enough to completely cover the surface with plaster of Paris, powclered chalk or slaked lime.

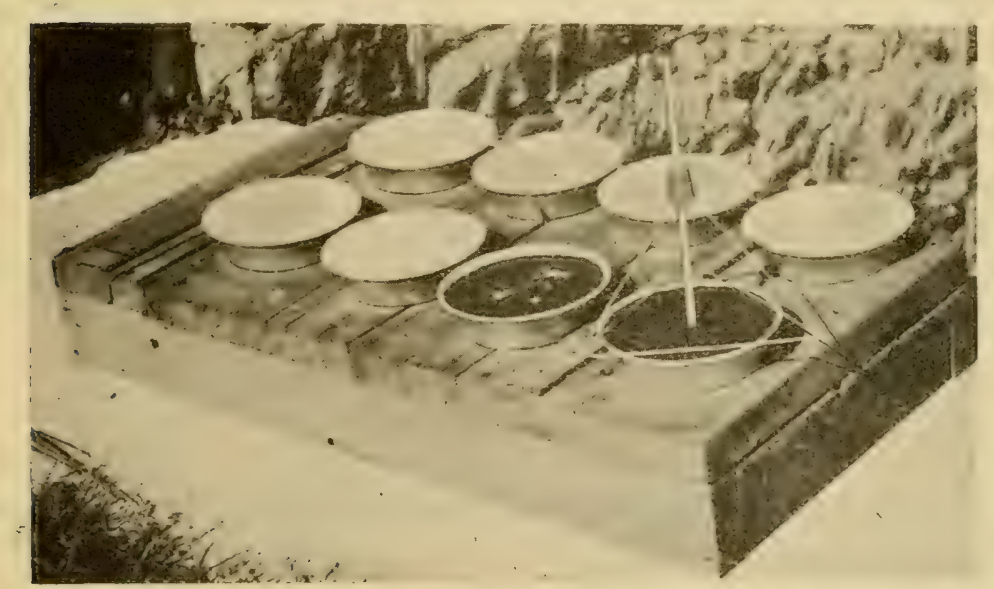

Fig. 12. Showing the pans of soil as they appear in Experiment XIX.

Note- In filling the mus, fill wans $1,2,3,4$ and 5 romuling full and tap theil sides with a stick to settle the soit. Then with a straight edge strike off the sturface of the soil even with the rim of the pan. Fill pans 6, 7 and 8 rounding full, tap the sides very lightly, strike off and tap again to complete the settling; the idea being to so gauge the tapjing before and after striking off that when the settling is complete, there will be just room enough to hold the required anomit of the covering material to completely cover the surface of the soil proper. It may resuire more than one trial to aceomplish the best results.

2. Set all of these pans with their contents out in the sunshine. (It will be better if the pans can be set down into the ground so that their rims stand just even with the surface of the ground. The rims of the pans should be but a few inches apart.)

3. At any time between $11 \mathrm{a} . \mathrm{m}$. and $2 \mathrm{p}$. m. take the temperature of these soils one inch below the surface and record.

Note-It will not be necessary to make a hole for the thermometers in these soils. Carefully ousli the bulb of the thermometer to the proper depth. An open frame or gauge like that shown in Fig. 12 will prove helpful.

4. In order that the results may he more reliable it will be better to take the thermometer readings just, 5 minutes apart, taking two reading: from each pan. Take the readings in the following order: 1, 2, 3, 4, $5,6,7,8,8,7,6,5,4,3,2,1$.

Place your readings in a table like this: 
Effect of Color on Soil Temperatures.

$$
\begin{aligned}
& \begin{array}{c|c|c|c|c|c|c|c}
\hline \text { Pan } & \text { Pan } & \text { Pan } & \text { Pan } & \text { Pan } & \text { Pan } & \text { Pan } & \text { Pan } \\
1 . & 2 . & 3 . & 4 . & 5 . & 6 . & 7 . & 8 .
\end{array} \\
& \text { 氰| }
\end{aligned}
$$

Firs rading:

Feronel rearlings

Average temperatures..

( )roter of trmperature.

5. Average the first and secound rearlings of each pan, placing the average: in the proper plate and indicate order of temperatures, from highest fo lowest.

6. Place all of the pans under cover and away from the sunshine, and after twenty-fom hours, with the pans still in the sharle, take the temperatures as in 4, introducing the realings into a talsle like the one nserl for the readings of the previous day.

7. Complete the table as in 5 .

S. Record any conclusions suggested by this experiment.

\section{EXPERIMENT XX.}

\section{Effect of Color upon Soil Temperature (with moist soils and field conditions).}

Apparatus and materials needed:

A spade.

22 linear feet of $\frac{1}{2}$-in. $x$ 6-in. boards.

8 carefully graduated all-glass thermometer's.

1 iron rod to make holes for the thermometers.

$\frac{1}{2}$ bu, each of the following soils: a clay, a light loam, a llark lonm, a sandy, and a muck.

\section{The experiment:}

1. From a level area $2 \mathrm{ft}$. $x 4 \mathrm{ft}$. remove the soil to the uniform depth of 7 inches.

2. Cover the bottom of the excavation so formed to the depth of one inch, when well packed, with coarse sand.

3. With the $\frac{1}{2}-\mathrm{in}$. $\times$ 6-in. boarts rivide this area into srfuares of about. one foot on each side and six inches deep.

4. Fill these squares as follows:

a. With a clay soil, finely crumbled.

b. With a light colored loam, finely crumbled.

c. With a dark colored loam, finely crumbled.

d. With a fine sandy soil, finely crumbled.

e. With a muck soil, finely crumbled.

f. With a clay soil, fincly crumbled, leaving room for just enough muck soil to completely cover the surface of the clay. 
g. With finely crumbled muck soil, leaving room for just enough of the finely crumbled (lay soil to completely cover the surface of the muck.

h. With finely crumbled nutek soil, leaving room for just mumbly plaster of Paris, ground ehalk or slaked lime to enmpletely cover the surfare of the muck.

5. With a garden sprinkler and water thoroughly wet rown the soils in all of these divisions. A good rain would do the work better.

6. Allow to stand twenty-four hours.

7. On the first sunshiny day set one of the eight themometers to the depth of two inches in the center of each of the eight areas, using the iron rod if necessary to make holes for the bullos of the thermometers. Nake and record readings at 10 \%. m., $12 \mathrm{~m}$, and $2 \mathrm{p} . \mathrm{m}$.

S. On the first clourly day set the thermometers as indicated in 7 and make and record readings at $10 \mathrm{a}, \mathrm{m}, 12 \mathrm{~m}$., aurl $2 \mathrm{p} . \mathrm{m}$.

Use. a table like this:

Effect of Color on Soil Temperature.

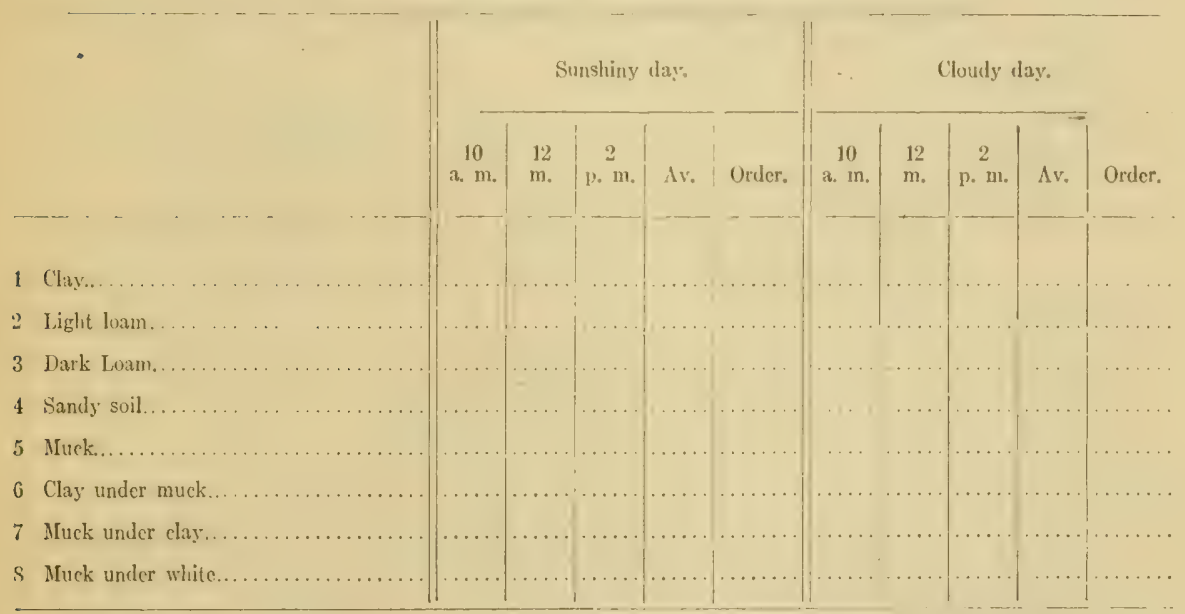

Do the results suggest any methods for practice on the farm?

\section{EXPERIMENT XXI.}

\section{The Effect of Moisture upon the Temperature of the Soil.}

Apparatus and materials needed:

2 one-quart pudding or bean pans.

3 quarts finely crumbled, air-dry, sandy soil.

1 carefully graduated all-glass thermometer.

The experiment:

1. Fill the two pans with the soil in the manner described in Experiment XIX.

2. Thoroughly moisten the soil in one of the pans and allow both pans of soil to stand together in the laboratory, but away from the sunshine, for a few hours. 
3. Determine and record the temperature of the soil in the two pans.

4. Now place the pans in the sunshine, and after two hours determine and record temperature.

Use a table like the following:

Soil Temperatures as Influenced by Light and Moisture.

\begin{tabular}{|c|c|c|}
\hline & $\begin{array}{c}\text { In } \\
\text { shade. }\end{array}$ & $\begin{array}{c}\text { In } \\
\text { sunshine. }\end{array}$ \\
\hline \multicolumn{3}{|l|}{ 1) ryil. } \\
\hline Wet soil... & & \\
\hline Difference. & & \\
\hline
\end{tabular}

5. How wet should a field soil be?

Why so wet?

Why not wetter?

It might be well to repeat this experiment, nsing other soils.

Experhant XXII.

Effect of Tilth upon the Temperature of the Soil.

Apparalus needed:

A sparle.

2 all-glass thermometers, accurately graduated.

An iron rod to make holes for the themometers.

The experiment:

1. Select a bare level field or garden area 1 foot by 2 feet -one that has not recently been plowed or spaded.

2. Thoroughly spade one-half of this area to the depth of six inches. If the soil does not crumble freely, it should be removed, placed in a pile, and thoromghty crmblyed with the hatuls if necessary, and then returned to its place.

Leave the other half unspaded.

3. With the iron rod make a hole in the center of each half of the area, sufficiently deep to receive its thememeter to the depth of two inches.

4. At one o chock on the first clear day place the thermometers one in each of these holes and after 5 minutes read and record temperatures.

5. At one o'clock on the first clomly day place the thermometers one in each hole and after 5 minutes read and record the temperatures,

Use a table like this: 
Soil Temperatures as Influenced by Light and Cultivation.

Uncultivated..

Cultivated

Difference.

It may be desirable to make several readings at the hours indicated.

It might be interesting also to make readings at other hours.

6. If you discover differences in temperatures account for them.

7. Do the results suggest any methods of farm practice?

\section{Experiment XXIII.}

\section{Effect of Smoothness of Surface upon Soil Temperature.}

Apparatus needed:

A spade.

A garden rake.

2 carefully graduated all-glass thermometers.

An iron rod to make holes for the thermometers.

\section{The experiment:}

1. Select a level field or garden area two feet by four feet, one that has not recently been plowed or spaded.

2. Spade the whole area to a depth of six inches.

3. With the rake level off one-half ( $2 \mathrm{ft} . \mathrm{x} 2 \mathrm{ft}$.) of the spaded area, and with the spade pat down the surface even and smooth so as to resemble the rolled surface of a field.

4. The remaining area should not be smoothed. The more rough and lumpy it can be left the better.

5. On the first sunshiny day carefully set the thermometers, one in the center of each of these areas, to the depth of two inches below the surface of the ground, and make and record readings at $8 \mathrm{a} . \mathrm{m} ., 10 \mathrm{a} . \mathrm{m}$., $12 \mathrm{~m} ., 2$ p. m., and 4 p. $\mathrm{m}$.

Be careful on the rough area not to measure down from the top of the lumps, but from the top of the ground.

6. On the first cloudy day set the thermometers as above and make and record readings.

Use a table like this: 
Effect of Smoothness of Surface upon Soil Temperature.

\begin{tabular}{|c|c|c|c|c|c|c|c|c|c|c|c|c|}
\hline & \multicolumn{6}{|c|}{ Bright day. } & \multicolumn{6}{|c|}{ Cloudy day. } \\
\hline & a. $\stackrel{8}{\mathrm{~m}}$. & $\begin{array}{c}10 \\
\text { a. m. }\end{array}$ & $\begin{array}{l}12 \\
\mathrm{~m} .\end{array}$ & p. $\stackrel{2}{m}$ & p. $\frac{4}{m}$. & Average. & $\stackrel{8}{\text { a. } m .}$ & $\begin{array}{c}10 \\
\text { a. } \mathrm{m}\end{array}$ & $\begin{array}{l}12 \\
\mathrm{~m} .\end{array}$ & p. $\stackrel{2}{\mathrm{~m}}$ & $\begin{array}{c}4 \\
\text { p. } m .\end{array}$ & Average. \\
\hline Smooth surface.... & & & & & & & & & & & & \\
\hline Rough surface..... & & & & & & & & & & & & \\
\hline Difference... & & & & & & & & & & & & \\
\hline
\end{tabular}

7. Fill out the table.

Shall we roll our fields? Give reason for your answer.

8. Study and compare results obtained in this experiment.

Do the results in the two experiments indicate conflicting farm practice.

The question concerning the rolling of fields suggests a modification of the experiment with dry earth mulches.

In the jars supplied with water from the bottom once each week determine the moisture content of the two-inch mulch. Then after a fresh watering: press down a portion of this mulch against the tamped soil below. After several hours determine its moisture content again and compare with first result.

Why is a fine harrow used after rolling? 



\section{LIBRARY OF CONGRESS}

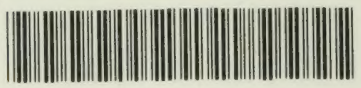

000238157?? 